\title{
Image of an Unusual Thyroid Nodule
}

Wan Xin Yew ${ }^{1}$, Mechteld C De Jong ${ }^{2}$, Rajeev Parameswaran ${ }^{3}$

Keywords: Imaging, Thyroid nodule, Thyroid ultrasound.

World Journal of Endocrine Surgery (2021): 10.5005/jp-journals-10002-1404

\section{Case Description}

A 54-year-old female presented to the endocrine surgery clinic after a $0.7-\mathrm{cm}$ hypointense nodule in her left thyroid lobe was incidentally detected on a T2-weighted MRI-scan of her cervical spine, for investigation of chronic neck aches.

She did not have any pain, symptoms of hyperthyroidism, or compressive symptoms such as dysphagia, dyspnea, or change of voice. Her past medical history included chronic migraines, latent hepatitis B, and hyperlipidemia. There was a negative family history for thyroid issues. Clinical examination of the neck was essentially normal with no palpable thyroid nodule, and she was clinically euthyroid. A thyroid function test was within normal range [T4 $11.5 \mathrm{pmol} / \mathrm{L}$ and thyroid-stimulating hormone (TSH) $2.48 \mathrm{mIU} / \mathrm{L}]$. Her adjusted calcium was $2.24 \mathrm{mmol} / \mathrm{L}$.

Ultrasound scan of her thyroid showed a well-circumscribed nodule at the posterior interpolar region of the left thyroid lobe, with calcifications seen within and a hypoechoic rim (Fig. 1). No suspicious cervical lymphadenopathy was noted. The patient subsequently underwent ultrasound-guided fine needle aspiration (FNA) of this nodule. Cytology showed the presence of squamous cells, with no colloid or thyroid follicles.

\section{What is the diagnosis?}

- Squamous cell carcinoma of the thyroid

- Esophageal lesion

- Dermoid cyst

- Lymphoepithelial cyst

\section{Answer:}

- Esophageal lesion
${ }^{1}$ Yong Loo Lin School of Medicine, Singapore

2,3 Department of Endocrine Surgery, National University Hospital, Singapore

Corresponding Author: Rajeev Parameswaran, Department of Endocrine Surgery, National University Hospital, Singapore, Phone: +6591271524 e-mail: rajeev_parameswaran@nuhs.edu.sg

How to cite this article: Yew WX, De Jong MC, Parameswaran R. Image of an Unusual Thyroid Nodule. World J Endoc Surg 2021;13(2):68-69.

Source of support: Nil

Conflict of interest: None

\section{Discussion}

A CT scan of the neck was performed, which showed a lesion contiguous with the esophagus and with presence of air centrally, features suggestive of a Killian-Jamieson diverticulum (KJD). She was subsequently referred for an esophagogastroduodenoscopy for further evaluation.

KJD is an uncommon form of esophageal diverticulum resulting from herniation through a weakness in the anterolateral wall of the proximal cervical esophagus, just caudal of the cricopharyngeus. Its incidence is about $0.025 \%$ of the population, typically affecting the elderly, ${ }^{1}$ and could initially be mistaken for a thyroid nodule, ${ }^{2,3}$ due to the proximity of the upper esophagus to the thyroid gland.

Due to presence of food particles and air bubbles within the diverticulum, a heterogeneous internal echo with strong echogenic foci may be seen on ultrasound and may be mistaken to be suspicious microcalcifications of thyroid cancer. Observing for changes of the size and contents of the lesion during swallowing of water or compression with the ultrasound probe can help to raise suspicion that the nodule is not of thyroid origin. ${ }^{3}$

() The Author(s). 2021 Open Access This article is distributed under the terms of the Creative Commons Attribution 4.0 International License (https://creativecommons. org/licenses/by-nc/4.0/), which permits unrestricted use, distribution, and non-commercial reproduction in any medium, provided you give appropriate credit to the original author(s) and the source, provide a link to the Creative Commons license, and indicate if changes were made. The Creative Commons Public Domain Dedication waiver (http://creativecommons.org/publicdomain/zero/1.0/) applies to the data made available in this article, unless otherwise stated. 


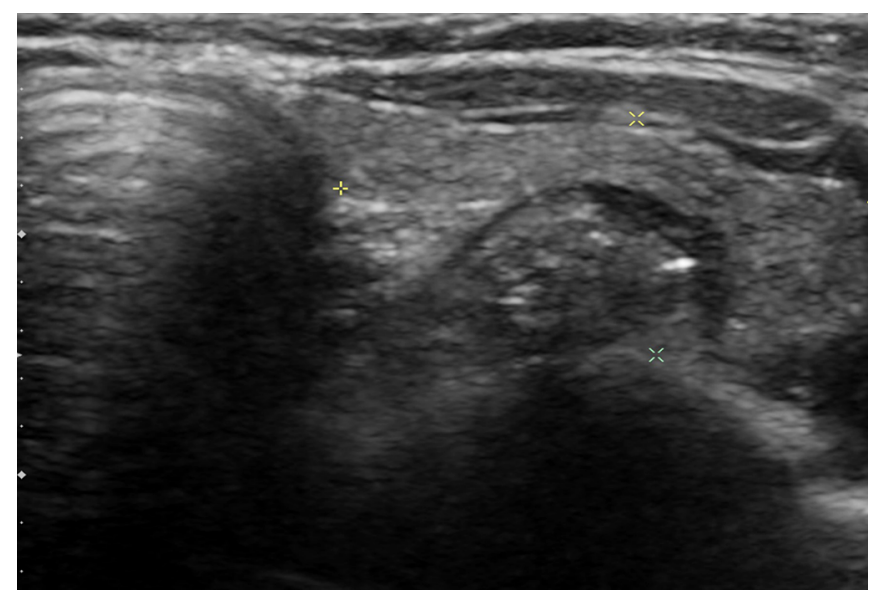

Fig. 1: Ultrasound scan showing the nodule in the left thyroid lobe
Evaluation of an esophageal diverticulum should be done through fluoroscopic swallow studies or an esophagogastroduodenoscopy. It is important to consider esophageal diverticulum as a differential of an atypical thyroid nodule to avoid unnecessary invasive testing.

\section{References}

1. Stewart KE, Smith DRK, Woolley SL. Simultaneously occurring Zenker's diverticulum and Killian-Jamieson diverticulum: case report and literature review. J Laryngol Otol 2017;131(8):661-666. DOI: $10.1017 /$ S0022215117001268

2. Matsuura H, Kishida M, Sasaki E. Mimicking a Thyroid Nodule: Killian-Jamieson Diverticulum. Am J Med Sci DOI: 10.1016/j. amjms.2020.12.014

3. Kim HK, Lee Jl, Jang HW, et al. Characteristics of Killian-Jamieson diverticula mimicking a thyroid nodule. Head Neck 2012;34(4): 599-603. DOI: 10.1002/hed.21575 